\title{
ANALISIS SEQUENTIAL EXPLORATORY HUBUNGAN POLA ASUH PENDIDIKAN KELUARGA DENGAN PRESTASI BELAJAR PADA MATA PELAJARAN FIQH DI MTS SATU ATAP (SA) NURUL HUDA CURUG WETAN
}

\author{
Zulkifli \\ zulkifli@umt.ac.id \\ (Fakultas Agama Islam, Universitas Muhammadiyah Tangerang) \\ Erpin Harahap \\ erpinharahap@umt.ac.id \\ (Fakultas Agama Islam, Universitas Muhammadiyah Tangerang) \\ Jelaviantie Wahidatul Romdiyany \\ jelaviantiel@gmail.com \\ (Program Studi Pendidikan Agama Islam, Fakultas Agama Islam, Universitas \\ Muhammadiyah Tangerang)
}

\begin{abstract}
Abstrak
Pola Asuh Pendidikan Keluarga adalah suatu proses interaksi antara orang tua, anak, dan juga lingkungan keluarga yang meliputi kegiatan seperti memelihara, mendidik, membimbing serta mendisiplinkan dalam mencapai proses kedewasaan baik secara langsung maupun tidak langsung tujuan dari penelitian ini adalah untuk mengetahui hubungan pola asuh pendidikan keluarga dengan prestasi belajar siswa kelas VIII pada mata pelajaran Fiqh di MTs Satu Atap (SA) Nurul Huda Curug Wetan. Penelitian ini menggunakan penelitian mixed methods. Metode Mixed methods (metode gabungan: kualitatif-kuantitatif) adalah metode dengan menggunakan gabungan pada prosedur penelitian, dimana salah satu metode lebih dominan terhadap metode yang lain. Metode yang kurang dominan hanya diposisikan sebagai metode pelengkap sebagai data tambahan. Adapun metode yang lebih dominan dalam penelitian ini adalah metode kualitatif dan sebagai metode pelengkapnya adalah metode kuantitatif. Pengambilan sampel dengan cara mengambil nomor urut absen ganjil dari keseluruhan siswa kelas VIII di MTs Satu Atap (SA) Nurul Huda Curug Wetan. Alat oengumoulan data dalam penelitian ini adalah observasi,wawancara, angket dan don dokumentasi. Dan Uji Hipotesis penelitian menggunakan uji $T$. berdasarkan hasil wawancara dan analisis data yang diperoleh dari uji t sebesar 2,251 dengan taraf signifikan 0,05 yaitu 2,051. Karena thitung = 2,251 > ttabel = 2,051 maka Ha diterima dan Ho ditolak. Kesimpulannya adalah terdapat hubungan antara pola asuh pendidikan keluarga dengan prestasi belajar siswa pada mata pelajaran fiqh di MTs Satu Atap (SA) Nurul Huda Curug Wetan.
\end{abstract}

\section{Kata Kunci : Pola Asuh Pendidikan Keluarga, Prestasi Belajar}

\begin{abstract}
Family Education Parenting is a process of interaction between parents, children, and also the family environment which includes activities such as nurturing, educating, guiding and disciplining in achieving the maturity process, either directly or indirectly. The purpose of this study is to determine the relationship of educational parenting. family with student achievement in class VIII in the Fiqh subject at MTs One Roof (SA) Nurul Huda Curug
\end{abstract}


Wetan. This research uses mixed methods research. Mixed methods (combined methods: qualitative-quantitative) are methods that use a combination of research procedures, where one method is more dominant over the other method. The less dominant method is only positioned as a complementary method as additional data. The method that is more dominant in this research is the qualitative method and as a complementary method is the quantitative method. Sampling was taken by taking the odd absent serial number of all grade VIII students at MTs One Roof (SA) Nurul Huda Curug Wetan. The means of collecting data in this research are observation, interview, questionnaire and documentation don. And the research hypothesis test using the T test based on the results of interviews and data analysis obtained from the $t$ test of 2.251 with a significant level of 0.05, namely 2.051. Because tcount $=$ $2.251>$ ttable $=2.051$ then Ha is accepted and Ho is rejected. The conclusion is that there is a relationship between family education parenting and student achievement in fiqh subjects at MTs One Roof (SA) Nurul Huda Curug Wetan.

\section{Keywords: Family Education Parenting, Learning Achievement}

\section{A. Pendahuluan}

Di dalam pembukaan UUD 1945 dinyatakan bahwa tujuan membentuk Negara Kesatuan Republik Indonesia ialah untuk "mencerdaskan kehidupan bangsa". ${ }^{1}$ Bangsa yang cerdas adalah bangsa yang dapat bertahan (survive) di dalam menghadapi kesulitan. Pendidikan dianggap menjadi salah satu upaya untuk mewujudkan tujuan yang telah tercantum dalam pembukaan UUD 1945 tersebut. Pendidikan merupakan suatu investasi yang paling berharga dalam bentuk peningkatan kualitas sumber daya manusia untuk pembangunan suatu bangsa. Bangsa yang besar dapat diukur dari kualitas masyarakatnya dalam mengenyam pendidikan tinggi pendidikan yang dimiliki oleh suatu masyarakat, maka semakin majulah bangsa tersebut.

Bagi manusia pendidikan merupakan suatu keharusan, karena dengan pendidikan kemampuan dan kepribadian manusia akan berkembang. Pendidikan bisa kita dapatkan dimana saja, baik di sekolah, di dalam lingkungan keluarga, dan di lingkungan masyarakat. Akan tetapi pendidikan yang paling mendasar adalah

\footnotetext{
${ }^{1}$ MK. Abdullah, UUD '45: Jakarta: Pustaka Sandro Jaya, t.t.), h.5
}

pendidikan yang didapatkan di dalam lingkungan keluarga. Karena bagaimanapun, antara lingkungan keluarga dan pendidikan adalah dua istilah yang tidak dapat dipisahkan, sebab dimana ada keluarga disitu pasti ada pendidikan. Ketika ada orang tua yang ingin mendidik anaknya, maka pada waktu yang sama anak mendapatkan pendidikan dari orang tua. Dari sini muncullah istilah "pendidikan keluarga". Artinya pendidikan yang berlangsung dalam lingkungan keluarga yang dilaksanakan oleh orang tua sebagai tugas dan tanggungjawabnya dalam mendidik anak dalam keluarga ${ }^{2}$.

Pendidikan keluarga adalah dasar bagi pendidikan anak, selanjutnya hasilhasil pendidikan yang diperoleh anak dalam keluarga menentukan pendidikan anak itu disekolah maupun di masyarakat. Dengan kata lain orang tua sebagai penanggung jawab pendidikan yang pertama dan yang utama. Dikatakan yang pertama karena sebelum anak sekolah dia telah mengenal terlebih dahulu lingkungan keluarga dan dikatakan yang utama karena pendidikan dalam keluarga merupakan

${ }^{2}$ Syaiful Bahri Djamarah, Pola Asuh Orangtua dan Anak Dalam Keluarga, (Jakarta: Rineka Cipta, 2004), h. 2. 
landasan atau dasar untuk perkembangan anak pada masa selanjutnya. Pendidikan keluarga dapat diartikan sebagai usaha dan upaya orang tua dalam memberikan bimbingan, pengarahan, pembinaan dan pembentukan kepribadian anak serta memberikan bekal pengetahuan terhadap anak Allah SWT berfirman dalam Q.S Luqman ayat 13-19 tentang salah satu contoh orangtua yang bijak dalam mendidik anak nya. Dia adalah Luqman alHakim. Julukan Al-Hakim menunjukkan bahwa ia adalah tokoh yang memiliki pemahaman dan pengalaman luas dalam menangani persoalan umat termasuk di dalamnya dalam mencetak generasi unggulan. Indikatornya Nampak dalam materi pembelajaran yang di persiapkan untuk mendidik anaknya yang meliputi akidah, ibadah dan akhlak mulia. Ketiga materi ini merupakan materi paling fundamental dalam mencetak karakter peserta didik. ${ }^{3}$

Prestasi belajar merupakan pencapaian hasil belajar siswa setelah menempuh mata pelajaran tertentu, dalam hal ini dapat dilihat dari nilai rapor yang diperoleh. Akan tetapi, pencapaian hasil belajar kadangkala tidak sesuai dengan yang diharapkan sehingga berakibat pada hasil belajar siswa yang menurun. Selain prestasi akademik juga dapat di lihat dari prestasi non akademik seperti juara lomba. Masalah hasil prestasi siswa yang berbedabeda diduga dipengaruhi oleh beberapa faktor diantaranya pola asuh orangtua Faktor-faktor yang mempengaruhi prestasi banyak jenisnya, akan tetapi dapat digolongkan menjadi dua golongan saja, yaitu faktor intern dan faktor ekstern. Faktor intern adalah faktor yang ada dalam diri individu yang sedang belajar, seperti kesehatan (jasmani dan rohani), inteligensi,

\footnotetext{
${ }^{3}$ Muhammad Bashri Asya'ari dan Ahmadi Usman, Tarbiyah dalam frame Islam, (Yogyakarta: Nameela Yogyakarta,2018), h. 149.
}

bakat, minat, motivasi, cara belajar. Sedangkan faktor ekstern adalah faktor yang ada di luar individu. Seperti pola asuh Orang tua, sekolah, masyarakat, lingkungan sekitar. Pola asuh orangtua merupakan faktor ekstern yang mempengaruhi prestasi siswa karena orangtua berperan penting dalam kebiasaan belajar anak, anak mengikuti cara belajar yang diajarkan orangtua dan orangtua akan memberikan dampak terhadap hasil belajar anak. Cara orangtua mendidik anaknya berbeda-beda, ada yang menggunakan pola asuh bersifat penyabar, ada yang sangat menuntut, dan ada juga yang tidak pernah sama sekali menuntut. Pola asuh dibagi dalam tiga macam, yaitu pola asuh authoritarian (otoriter), pola asuh Permisif, dan pola asuh demokratif. Sebagian orang tua ada yang menerapkan pola asuh otoriter (sangat kuat dan cukup ketat dalam mengontrol perilaku anak sehingga menghambat munculnya komunikasi terbuka antara orang tua dan anak), demokrasi (memberlakukan peraturanperaturan yang dibuat bersama oleh anggota keluarga yang bersangkutan), dan permisif (selalu memberi kebebasan sebanyak mungkin kepada anak untuk mengatur dirinya). Namun pengasuhan yang seperti ini kurang kondusif, karena gaya pengasuhan yang diterapkan oleh orang tua sangat mempengaruhi hasil prsetasi belajarnya.

Menurut informasi yang berupa wawancara yang dilakukan oleh peneliti dengan Wali Kelas VIII MTs Satu Atap (SA) Nurul Huda Curug Wetan terdapat perbedaan nilai dari siswa Kelas VIII di MTs tersebut ${ }^{4}$. Nilai yang diperoleh siswa kelas VIII berkisar antara 60 sampai 95, sehingga terdapat selisih nilai sebesar 35 . Sedangkan prestasi belajar yang diperoleh

\footnotetext{
${ }^{4}$ Wawancara Pribadi dengan wali kelas VIII Mts Satu Atap (SA) Nurul Huda Curug Wetan, Tangerang, 30 April 2020
} 
siswa kelas VIII tersebut dipengaruhi oleh berbagai faktor internal dan eksternal. Faktor eksternal salah satunya dengan pemberian pola asuh orangtua kepada anaknya. Diperoleh informasi bahwa siswa yang bersekolah di MTs tersebut berasal dari berbagai kalangan, mulai dari kalangan orangtua yang sibuk bekerja hingga orang tua yang hanya menjadi ibu rumah tangga. Keluarga memiliki sumbangan yang cukup besar bagi prestasi belajar tiap anak yang diberikan melalui pola asuh.

Permasalahan yang dihadapi di MTs Satu Atap (SA) Nurul Huda Curug Wetan antara pola asuh pendidikan keluarga dengan prestasi belajarnya ini adalah latar belakang keluarga siswa yang berbeda-beda dalam menerapkan jenis pola pengasuhan. ${ }^{5}$ ada yang menerapkan pola pengasuhan otoriter, demokratis, permisif. Ada yang berasal dari keluarga yang merawat, mendidik, membimbing terhadap aktivitas belajar anak serta memperlakukan anak dengan baik dan ada juga yang berasal dari keluarga acuh tak acuh terhadap aktivitas belajar anak, anak diperlakukan dengan kasar sehingga tidak memperhatikan psikologis anaknya, anak yang memiliki orangtua yang super sibuk sehingga anak di asuh oleh pembantu. Semua variasi yang beragam ini mempunyai pengaruh pada anak dalam minat dan motivasi belajar, sehingga mempengaruhi pula pada prestasi belajarnya. Berdasarkan uraian diatas, maka peneliti tertarik untuk melakukan penelitian tentang "Analisis Sequential Exploratory Hubungan Pola Asuh Pendidikan Keluarga Dengan Prestasi Belajar Siswa Pada Mata Pelajaran Fiqh Di Mts Satu Atap (Sa) Nurul Huda Curug Wetan.

\footnotetext{
${ }^{5}$ Wawancara Pribadi dengan Kepala Mts Satu Atap (SA) Nurul Huda Curug Wetan, Tangerang, 30 April 2020
}

\section{B. Kajian Teori}

Pola asuh Pendidikan Keluarga adalah suatu proses interaksi antara orang tua, anak, dan juga lingkungan keluarga yang meliputi kegiatan seperti memelihara, mendidik, membimbing serta mendisiplinkan dalam mencapai proses kedewasaan baik secara langsung maupun tidak langsung. Jenis-jenis Tipe Pola Asuh Pendidikan Keluarga

1. Pola Asuh Otoriter. Menurut Singgih D. Gunarso pola asuh otoriter adalah "cara mengasuh anak yang dilakukan oleh orang tua dengan menentukan sendiri aturanaturan dan batasan-batasan yang mutlak, harus ditaati oleh anak tanpa compromised dan tanpa memperhitungkan keadaan dan kemampuan anak. ${ }^{6}$

2. Pola Asuh Demokratis. Tipe pola asuh demokratis adalah tipe pola asuh yang terbaik dari semua tipe pola asuh yang ada. Hal ini disebabkan tipe pola asuh ini selalu mendahulukan kepentingan bersama di atas kepentingan individu anak Tipe pola asuh demokratis mengharapkan anak untuk berbagi tanggung jawab dan mampu mengembangkan potensi kepemimpinan yang dimilikinya.

3. Pola Asuh Permisif. Pola asuh permisif kebalikan dari pola asuh otoriter. Dalam pola asuh permisif dapat diartikan sebagai pola perilaku orang tua dalam berinteraksi dengan anak, yang membebaskan anak untuk melakukan apa yang ingin di lakukan tanpa mempertanyakan. Dalam pembentukan kepribadian anak kedua orangtua harus mampu berusaha memperkenalkan hal-hal positif di lingkungan maupun keluarga. ${ }^{7}$

Prestasi belajar merupakan hasil yang telah diperoleh oleh siswa setelah

${ }^{6}$ Zakky Ramdhani Muslim, "Hubungan Pola Asuh Orang Tua terhadap Prestasi Belajar bahasa indonesia siswa kelas X di SMK Kemala Bhayangkara Delog Jakarta", (Skripsi S1 Universitas Islam Negeri (UIN) Syarif Hidayatullah Jakarta, 2017) h. 8

${ }^{7}$ Zulkifli, Pengantar Studi Islam, (Tangerang:Uwan, 2016).h. 23 
melaksanakan kegiatan belajar tertentu, baik berupa pengetahuan, sikap ataupun keterampilan (ranah kognitif, afektif dan psikomotorik) ketika mereka di sekolah. Prestasi belajar siswa tersebut dapat diukur melalui tes yang diberikan oleh guru dan biasanya dinyatakan dalam bentuk angka (skor) yang ditulis oleh guru dalam buku prestasi belajar siswa (raport).

Faktor-faktor yang mempengaruhi prestasi belajar, sebagai berikut :

1. Faktor Internal. Faktor Intern adalah faktor-faktor yang berasal dari dalam diri individu dan dapat mempengaruhi prestasi belajar individu. Adapun faktor internal meliputi kesehatan, inteligensi, bakat, minat, motivasi, cara belajar

2. Faktor Eksternal. Faktor Intern adalah faktor-faktor yang berasal dari dalam diri individu. Adapun faktor eksternal meliputi pola asuh Orang Tua, sekolah, masyarakat, lingkungan Sekitar.

Mata pelajaran Fiqih merupakan mata pelajaran bermuatan Pendidikan Agama Islam yang memberikan pengetahuan tentang ajaran Islam dalam segi hukum Syara' dan membimbing siswa agar memiliki keyakinan dan mengetahui hukum-hukum dalam Islam dengan benar serta membentuk kebiasaan untuk melaksanakannya dalam kehidupan seharihari. Pembelajaran fiqih berarti proses belajar mengajar tentang ajaran Islam dalam segi hukum Syara' yang dilaksanakan di dalam kelas antara guru dan siswa dengan materi dan strategi pembelajaran yang telah direncanakan.

\section{Metode Penelitian}

Penelitian ini dilaksanakan di MTs Satu Atap (SA) Nurul Huda Curug Wetan. Sampel yang digunakan dalam penelitian dalam penelitian ini adalah kelas VIII dengan mengambil nomor urut absen ganjil setiap siswa dari keseluruhan Kelas VIII
MTs Satu Atap (SA) Nurul Huda Curug Wetan. Penelitian yang dilakukan adalah penelitian Mixed Methods. Metode Mixed methods (metode gabungan: kualitatifkuantitatif) adalah metode dengan menggunakan gabungan pada prosedur penelitian, dimana salah satu metode lebih dominan terhadap metode yang lain. Metode yang kurang dominan hanya diposisikan sebagai metode pelengkap sebagai data tambahan. Adapun metode yang lebih dominan dalam penelitian ini adalah metode kualitatif dan sebagai metode pelengkapnya adalah metode kuantitatif.

Terdapat dua jenis variabel penelitian yaitu variabel bebas dan variabel terikat. Variabel bebas merupakan variabel yang mempengaruhi atau yang menjadi sebab perubahannya atau timbulnya variabel terikat. Variabel bebas dalam penelitian ini yaitu Pola Asuh Pendidikan Keluarga. Sedangkan variabel terikat ialah variabel yang dipengaruhi atau yang menjadi akibat, karena adanya variabel bebas. Variabel terikat dalam penelitian ini yaitu prestasi belajar siswa

Pelaksanaan Penelitian

1) Pengajuan Surat Izin melalui Kepala MTs Satu Atap (SA) Nurul Huda Curug Wetan

2) Koordinasi dan Konsultasi dengan Kepala MTs Satu Atap (SA) Nurul Huda Curug Wetan serta ibu guru MTs Satu Atap (SA) Nurul Huda Curug Wetan

3) Penyusunan Skripsi.

4) Membuat Instrumen Penelitian.

5) Pengambilan Nilai Mata Pelajaran Fiqh Kelas VIII

6) Melaksanakan Observasi Kelas VIII Pada saat Proses Pembelajaran

7) Melakukan wawancara dengan Wali Murid

8) Pengambilan Data melalui Penyebaran Instrumen. 
9) Teknik uji persyaratan analisis ini adalah uji normalitas dan homogenitas. Uji normalitas data yang dilakukan dengan menggunakan uji Ch-Kuadrat. Uji homogenitas data yang dilakukan dengan menggunakan uji Bartlet

10) Uji hipotesis menggunakan uji t. Uji ini untuk mengetahui apakah hipotesis diterima atau ditolak, dilihat dari hasil uji t yang didapatkan, diketahui bahwa nilai thitung > nilai ttabel maka $\mathrm{Ha}$ diterima dan Ho ditolak, artinya terdapat hubungan antara pola asuh pendidikan keluarga dengan prestasi belajar pada mata pelajaran fiqh di MTs Satu Atap (SA) Nurul Huda Curug Wetan..

\section{Hasil Penelitian Dan Pembahasan}

Dari hasil penelitian yang dilakukan mengenai hubungan pola asuh pendidikan keluarga dengan prestasi belajar siswa pada mata pelajaran fiqh di MTs Satu Atap (SA) Nurul Huda Curug Wetan. Maka diperoleh hasil penelitian sebagai berikut:

1) Penelitian yang penulis lakukan dengan wawancara terkait jenis tipe pola asuh pendidikan keluarga

a. Pola Asuh Pendidikan Keluarga yang bersifat otoriter yaitu seperti penerapan yang dilakukan oleh Ibu Yanah, sebagaimana hasil wawancara: "Saya mendidik anak saya lumayan keras dalam kedisiplinan, contohnya setelah isya Sonia harus mengerjakan PR kemudian jam 21:00 dia harus sudah tidur supaya paginya dia segar dan ketika belajar di kelas tidak ngantuk, dan saya juga mengharuskan dia bangun ketika sudah waktu subuh, supaya dia terbiasa melakukan sholat subuh".

\footnotetext{
${ }^{8}$ Wawancara Pribadi dengan ibu Yanah, Tangerang, 28 Agustus 2020
}

b. Pola Asuh Pendidikan Keluarga yang bersifat demokratis yaitu seperti penerapan yang dilakukan oleh Ibu Sari, "Sebagai Orang Tua kami menyadari akan pentingnya pendidikan bagi anak, khususnya pendidikan agama dan juga akhlak nya anak, maka dari itu kami slalu menemani nya ketika belajar diluar sekolah (di rumah), kami menemani nya belajar dan mengerjakan tugas dan kami pun mengajari nya dalam hal ibadah. Namun kami pun tidak memaksa nya untuk memahami suatu pelajaran yang sangat sulit untuk dipahami bagi mereka. Yang terpenting mereka sudah mau belajar dan tidak berhenti untuk mau mempelajarinya". 9

c. Pola Asuh Pendidikan Keluarga yang bersifat demokratis yaitu seperti penerapan yang dilakukan oleh Wati, beliau mengatakan "Kami menyadari betul bahwa pendidikan itu penting. Tapi kami juga memiliki kesibukan dalam bekerja, bukan kami tak ingin mengawasi kegiatan anak kami bagaimana, namun karena keterbatasan waktu maka kami membebaskan anak kami melakukan apapun yang mereka inginkan, namun masih dalam batas wajar dan tetap kami control ketika di waktu senggang kami. Dan karena keterbatasan waktu kami juga kami jadi jarang bisa menemaninya belajar dirumah. Maka dari itu kami memilih memasukannya ke tempat les dan privat mengaji"

Berdasarkan hasil dari wawancara di atas dapat disimpulkan bahwa pola asuh yang mudah diterapkan terhadap anak adalah dengan menggunakan pola asuh demokratis.

2) Uji normalitas (variabel $X$ ) dengan Chi-Kuadrat, diperoleh $=6,65$. Tabel Chi-Kuadrat dengan $\alpha$ 0,05 (taraf

\footnotetext{
${ }^{9}$ Wawancara Pribadi dengan Ibu Sari, Tangerang, 28 Agustus 2020
} 
sinifikan $5 \%$ ) sebesar $X^{2}$ hitung $=6,65$ $<\quad X^{2}$ tabel 11,07 yang berarti Ho diterima.

3) Uji normalitas (variabel Y) dengan Chi-Kuadrat, diperoleh $=8,98$. Tabel Chi-Kuadrat dengan $\alpha=0,05$ (taraf sinifikan 5\%) sebesar $X^{2}$ hitung 11,07 . $\mathrm{X}^{2}$ hitung $=8,98<\mathrm{X}^{2}$ tabel $=11,07$ yang berarti Ho diterima..

4) Uji Homogenitas (Variabel $X$ ) dengan Uji Bartlett, diperoleh $=1,765$. Xtabel dengan $\alpha$ 0,05 (taraf signifikan 5\%) sebesar $=9,49$. Maka $X^{2}$ hitung= $1,765<X^{2}$ tabel 9,49, yang berarti Ha diterima dan kelima data sampel berasal dari populasi yang homogen

5) Uji Homogenitas (Variabel Y) dengan Uji Bartlett, diperoleh $=2,709$. Xtabel dengan $\alpha 0,05$ (taraf signifikan 5\%) sebesar $=9,49$. Maka $X^{2}$ hitung $=7,342$ $<X^{2}$ tabel 9,49 yang berarti Ha diterima dan kelima data sampel berasal dari populasi yang homogen.

6) Uji Korelasi Product Moment Untuk mengetahui ada tidaknya hubungan tersebut maka dicari dengan persamaan sebagai berikut : Jika 0,480 > 0,381, maka Ha diterima dan interpretasi koefisien korelasi "Sedang".

7) Uji t (regresi sederhana), diperoleh 2,251 .

Pengujian hipotesis

Dari perhitungan di atas didapat nilai sebesar 2,251 dengan membandingkan pada nilai pada taraf $5 \%$ $(0,05)$ dengan $\mathrm{n}=29$ didapat $t_{\text {tabel }} 2,051$. Maka $t_{\text {hitung }}>t_{\text {tabel }}$ atau 2,251 $>2,051$. Dengan kata lain, Ha diterima dan Ho ditolak atau Terdapat hubungan yang signifikan antara pola asuh pendidikan keluarga dengan prestasi belajar siswa mata pelajaran fiqh di MTs Satu Atap (SA) Nurul Huda Curug Wetan

\section{E. Kesimpulan}

Berdasarkan hasil penelitiian ini dapat dibuktikan nilai rata-rata pola asuh pendidikan keluarga 62 dan nilai rata-rata prestasi belajar 80. Hal ini berdasarkan analisis data yang diperoleh dari uji $t$ sebesar 2,251 dengan taraf signifikan 5\% $(0,05)$ yaitu 2,051. Karena thitung $=2,251$ $>$ ttabel $=2,051$ maka Ha diterima dan Ho ditolak. Kesimpulannya adalah Terdapat hubungan antara pola asuh pendidikan keluarga dengan prestasi belajar siswa pada mata pelajaran fiqh di MTs Satu Atap (SA) Nurul Huda Curug Wetan.

\section{DAFTAR PUSTAKA}

Abdul Basyit, (2019), Kapita Selekta Pendidikan Islam, (Serang: CV Mandiri Print)

Ahmad Junaedi, (2017), Konsep Pendidikan Menu rut Luqmanul Hakim dalam Al-Qur'an, (Jurnal Passion of The Islamic Studies, Vol.1 No.2)

Fitriyah Indriyani, (2008). Pola Asuh Orang Tua Terhadap Anak Berprestasi di Sekolah, Skripsi S1 Jurusan Ilmu Pengetahuan Universitas Islam Negeri (UIN) Malang.

Hikmat kamal, (2009), Bingkai Keluarga Sakinah, (Tangerang: Pramita Press)

Ismail Marzuki, (2016), Model Pendidikan Pada Keluarga Imran, (Jurnal Rausyan Fikr, Vol.12 No. 2)

Juwariyah, (2010), Dasar-dasar Laut Pendidikan Anak dalam Al-Qur'an, (Yogyakarta: Teras)

M. Ainur Rasyid, (2017), Hadits-hadits Tarbawi, (Yogyakarta:Diva Press)

M. Dalyono, (2018), Psikologi Pendidikan, (Jakarta: PT.Rineka Cipta)

M. Ngalim Purwanto, (2014), Psikologi Pendidikan, (Bandung: PT: Remaja RosdaKarya) 
Analisis Sequential Exploratory Hubungan Pola Asuh Pendidikan Keluarga Dengan Prestasi Belajar Pada Mata Pelajaran Fiqh Di MTs Satu Atap (SA) Nurul Huda Curug Wetan

M. Syahran Jailani, (2014), Teori Pendidikan Keluarga dan Tanggung Jawab Orang Tua dalam Pendidikan Anak Usia Dini, ( Jurnal Pendidikan Islam, Vol. 8 No.2)

Moh Zaiful Rosyid, dkk., (2019), Prestasi Belajar, ( Batu: Literasi Nusantara)

Muhammad Bashri Asya'ari dan Ahmadi Usman, (2018) , Tarbiyah dalam frame Islam, (Yogyakarta: Nameela Yogyakarta)

Muhibbin Syah, (2014), Psikologi Pendidikan, (Bandung: PT. Remaja RosdaKarya)

Munirotul Hidayah, (2016), Pengaruh Pola Asuh Orang Tua terhadap Prestasi Belajar Siswa Kelas V A MI Ma'arif Bego Maguwoharjo Depok Sleman, Skripsi S1 Program Study Pendidikan Guru Madrasah Ibtidaiyah, Universitas Islam Negeri (UIN) Sunan Kalijaga Yogyakarta.

Muslima, (2015), Pola Asuh Orang Tua Terhadap Kecerdasan Finansial Anak, (Jurnal Gender Equality: Internasional Journal of Child and Gender Studies, Vol:. 1 No.1)

Nana Syaodih sukmadinata, (2017), Metode Penelitian Pendidikan, (Bandung: PT. Remaja RosdaKarya)

Rabiatul Adawiyah, (2017), Pola Asuh Orangtua Terhadap Implikasinya terhadap Pendidikan Anak", (Jurnal Pendidikan Kewarganegaraan, Vol.7 No. 1)

Sakinatush Shodiqoh (2018), Pengaruh Hasil Belajar Fikih Terhadap Praktik Shalat Siswa di MTs Negeri 4 Sleman, Sksipsi S1 Program Study Pendidikan Agama Islam Universitas Islam Indonesia (UII).

Satria Nurachmat (2018), Pengaruh Gaya Belajar Terhadap Prestasi Belajar Mata Pelajaran Menggambar Dengan Perangkat Lunak Kelas XI
Teknik Gambar di SMK Negeri 6 Bekasi', (Jurnal Teknil Sipil, Vol.7, No.1)

Sudardja Adiwikarta, (2016), Sosiologi Pendidikan, (Bandung: PT. Remaja Rosdakarya)

Sugiyono, (2016), Cara Mudah Menyusun Skripsi, Tesis dan Disertasi, (Bandung: Alfabeta)

Sugiyono, (2016), Metode Penelitian Kombinasi (Mixed Methods), (Bandung: Afabeta)

Sugiyono, (2015), Metode Penelitian Pendidikan, (Bandung: Alfabeta)

Syafaul Mudawam 2017), Syari'ah Fiqih Hukum Islam Studi tentang Konstruksi Pemikiran Kontemporer “. (Asy-Syir'ah: Jurnal Ilmu Syari'ah dan Hukum, Vol. 46 No. II, Juli- Des 2012).

Syaiful Bahri Djamarah, (2014), Pola Asuh Orangtua dan Anak Dalam Keluarga, (Jakarta: Rineka Cipta).

Syaiful Sagala, (2014), Konsep dan Makna

Pembelajaran, (Bandung: Alfabeta)

Syamsu Yusuf, (2016), Psikologi Perkembangan, (Bandung, PT Remaja RosdaKarya).

Zainal Arifin, (2016), Evaluasi Pembelajaran, (Bandung: PT. Remaja Rosda Karya).

Zakky Ramdhani Muslim, (2017), Hubungan Pola Asuh Orang Tua terhadap Prestasi Belajar bahasa indonesia siswa kelas $X$ di SMK Kemala Bhayangkara Delog Jakarta, Skripsi S1 Universitas Islam Negeri (UIN) Syarif Hidayatullah Jakarta.

Zulkifli, (2016), Pengantar Studi Islam,(Tangerang: Uwan)

Syaiful Bahri Djamarah, (2014), Pola Asuh Orangtua dan Anak Dalam Keluarga, (Jakarta: Rineka Cipta).

Syaiful Bahri Djamarah, (2014), Pola Asuh Orangtua dan Anak Dalam Keluarga, (Jakarta: Rineka Cipta). 
Analisis Sequential Exploratory Hubungan Pola Asuh Pendidikan Keluarga Dengan Prestasi Belajar Pada Mata Pelajaran Figh Di MTs Satu Atap (SA) Nurul Huda Curug Wetan

Zakky Ramdhani Muslim, (2017), Hubungan Pola Asuh Orang Tua terhadap Prestasi Belajar bahasa indonesia siswa kelas X di SMK Kemala Bhayangkara Delog Jakarta, Skripsi S1 Universitas
Islam Negeri (UIN) Syarif Hidayatullah Jakarta. 
Analisis Sequential Exploratory Hubungan Pola Asuh Pendidikan Keluarga Dengan Prestasi Belajar Pada Mata Pelajaran Fiqh Di MTs Satu Atap (SA) Nurul Huda Curug Wetan 